\title{
A INCONVENCIONALIDADE DO JULGAMENTO DE CIVIS PELA JUSTIÇA MILITAR DA UNIÃO SEGUNDO A JURISPRUDÊNCIA DA CORTE INTERAMERICANA DE DIREITOS HUMANOS
}

\author{
LA INCONVENCIONALIDAD DEL JUZGAMIENTO DE CIVILES POR LA \\ JUSTICIA MILITAR FEDERAL SEGUNDO LA JURISPRUDENCIA DE LA CORTE \\ INTERAMERICANA DE DERECHOS HUMANOS
}

${ }^{1}$ Luiz Magno Pinto Bastos Junior
${ }^{2}$ Rodrigo Mioto dos Santos

\section{RESUMO}

A estrutura constitucional de competências instituída pela Constituição da República Federativa do Brasil de 1988 (doravante CF/88 ou Constituição) estabeleceu que compete à justiça militar da União julgar os crimes militares, sem adentrar na qualificação dos réus. Ficando a definição de crime militar a cargo da legislação infraconstitucional, tem-se que o art. $9^{\circ}$ do Código Penal Militar (doravante CPM), instituído pelo Decreto-lei $\mathrm{n}^{\circ} 1.001$, de 21 de outubro de 1969, permite que o foro militar federal julgue civis. No entanto, a Convenção Americana sobre Direito Humanos (doravante Convenção) assegura, em seu art. 8, item 1, que toda pessoa tem direito a ser ouvida, com as devidas garantias e dentro de um prazo razoável, por um juiz ou tribunal competente, independente e imparcial, sendo que a Corte Interamericana de Direitos Humanos (doravante CorteIDH ou Corte), apenas reconhece à justiça militar frente a garantia da imparcialidade a competência para julgar militares por crimes que atentem exclusivamente contra bens ou interesses militares, o que cria uma evidente contrariedade com a possibilidade nacional de que a justiça militar da União julgue civis. Desse modo, o objetivo geral deste artigo consiste em verificar se (e em que medida) as hipóteses autorizadoras do julgamento de civis pela justiça militar da União compatibilizamse com a interpretação que a Corte Interamericana de Direitos Humanos confere ao disposto no art. 8, item 1, da Convenção, especificamente no que se refere às garantias da imparcialidade e da independência. Com esse fim, tem-se como objetivos específicos do escrito: (a) uma introdução sobre a estrutura e a competência da justiça militar no Brasil; (b) a delimitação da possibilidade de que a justiça militar da União julgue civis; (c) a verificação, por meio de precedentes, do exato sentido atribuído pela CorteIDH às garantias da imparcialidade e da independência, previstas no art. $8^{\circ}$, item 1, da Convenção, especificamente no que se refere à competência de tribunais militares; e, por fim, (d) a proposição de alterações que poderiam ser feitas na legislação brasileira, ou medidas que possam ser tomadas por juízes, a fim de adequar a regulação da matéria à jurisprudência da Corte. A fim de cumprir os objetivos de pesquisa, será adotado o método indutivo tendo em vista que o sentido da imparcialidade e da independência na Convenção, bem como dos limites do foro militar, serão extraídos a partir de análises de decisões da CorteIDH.

Palavras-chave: Competência da justiça militar para julgar civis, Imparcialidade, Independência, Corte interamericana de direitos humanos, Controle de convencionalidade

\footnotetext{
${ }^{1}$ Doutor em Direito pela Universidade Federal de Santa Catarina - UFSC, Santa Catarina (Brasil). Professor de Direito pela Universidade do Vale do Itajaí - UNIVALI, Santa Catarina (Brasil). E-mail: 1magno@univali.br

${ }^{2}$ Doutor em Direito pela Universidade Federal de Santa Catarina - UFSC, Santa Catarina (Brasil). Professor de Direito pela Universidade do Vale do Itajaí - UNIVALI, Santa Catarina (Brasil). E-mail: rms@ univali.br
} 


\section{RESUMEN}

La configuración constitucional de competencias establecida por la Constitución de la República Federativa de Brasil de 1988 (adelante CF/88 o Constitución) estableció que la justicia militar federal tiene competencia para juzgar los delitos militares sin entrar en la calificación de los acusados. Con la definición de delito militar a cargo de la legislación infraconstitucional, el artículo $9^{\circ}$ del Código Penal Militar (en adelante CPM), establecido por el Decreto-Ley $N^{\circ} 1001$, de 21 de octubre de 1969, permite al foro militar federal, el juzgamiento de civiles. Sin embargo, la Convención Americana sobre Derechos Humanos (en adelante la Convención) establece en su art. 8, punto 1, que toda persona tiene derecho a ser oída, con las debidas garantías y dentro de un plazo razonable, por un juez o tribunal competente, independiente e imparcial, mientras que la Corte Interamericana de Derechos Humanos (en adelante CorteIDH o Corte), reconoce sólo al foro militar diante de la garantía de lá imparcialidad - la competencia para enjuiciar a militares por delitos que violen exclusivamente bienes o intereses militares, lo que crea una molestia obvia con la posibilidad nacional que la justicia militar federal juzgue a un civil. Así, el objetivo general de este trabajo es verificar si (y en qué medida) el juzgamiento de civiles por la justicia militar federal es conciliada con la interpretación que la Corte Interamericana de Derechos Humanos (en ahora CorteIDH) otorga al dispuesto en el art. 8, punto 1, especialmente las garantías de imparcialidad e independencia. Así, tiene como objetivos específicos: (a) una introducción a la estructura y competencia de la justicia militar en Brasil; (b) la delimitación de la posibilidad de que los tribunales militares federales juzguen civiles; (c) la verificación a través de los precedentes, del significado exacto asignado por la CorteIDH para las garantías de imparcialidad e independencia, previstas en el art. 8, punto 1 de la Convención, específicamente con respecto a la jurisdicción de los tribunales militares ; y, por último, (d) proponer los cambios que podrían introducirse en la legislación brasileña, o medidas que pueden ser adoptadas por los jueces con el fin de adaptar la regulación de la materia a la jurisprudencia de la Corte. Con el fin de cumplir con los objetivos de la investigación, el método inductivo se adoptó con el fin de que el significado de imparcialidad e independencia en la Convención, así como los límites del foro militar, se extraen del análisis de las decisiones de la CorteIDH .

Palabras-claves: Competencia del foro militar para juzgar civiles, Imparcialidad, Independencia, Corte interamericana de derechos humanos, Control de convencionalidad 


\section{INTRODUÇÃO}

A estrutura constitucional de competências instituída pela Constituição da República Federativa do Brasil de 1988 estabeleceu duas justiças militares, a dos Estados e a da União, sendo a primeira competente para julgar os militares acusados de crimes militares, ao passo que a segunda ficou apenas com o encargo de julgar crimes militares, sem que a Constituição adentrasse na qualificação dos réus.

Ficando, pois, a definição de crime militar a cargo da legislação infraconstitucional, tem-se que o art. $9^{\circ}$ do CPM, instituído pelo Decreto-lei $n^{\circ} 1.001$, de 21 de outubro de 1969, permite que a Justiça Militar possa julgar civis acusados de crimes militares.

É certo que nos últimos anos a jurisprudência, especialmente do Supremo Tribunal Federal (doravante STF) tem restringido o alcance da competência da justiça militar da União, excluindo nas situações em que não se verifica uma autêntica "situação de interesse militar" (LOPES JR., 2013, p. 450). Porém, é pacífico no âmbito do STF a possiblidade de que civis sejam julgados pela justiça militar da União (p. ex. HC 121.189/PR).

A doutrina brasileira, ao seu turno, não costuma ver maiores problemas no fato de que a justiça militar da União possa a vir julgar civis. Aury Lopes Jr. (2013, p. 451-452) diz que a possibilidade é um retrocesso da Constituição de 1988 mas se conforma com a possibilidade. Eugênio Pacelli de Oliveira (2012, p. 251-253), apenas faz a exposição sobre a possiblidade, sem tecer qualquer crítica. Já Marcellus Polastri Lima (2012, p. 297), sequer menciona textualmente a possibilidade de que civis sejam julgados pela justiça militar da União.

Ocorre que, por ser o Brasil signatário da Convenção Americana sobre Direitos Humanos, desde 1992 passou a viger na ordem jurídica interna a garantia expressa de que todo acusado tem ser processado por um juízo "imparcial" (art. $8^{\circ}$, item 1), sendo que a CorteIDH entende que, quando um civil é julgado por uma justiça excepcional como a militar, ocorre ofensa a tal princípio.

Nesse sentido, o presente artigo científico tem por objetivo verificar se diante da jurisprudência da CorteIDH sobre a matéria, é compatível com a Convenção Americana de Direitos Humanos o julgamento, pela justiça militar da União, de civis.

No entanto, como já exposto, essa compatibilidade (ou sua ausência) será analisada não somente a partir da simples confrontação entre o ordenamento jurídico nacional e o texto normativo da Convenção. A análise pretende confrontar a legislação brasileira (na forma com que é compreendida pela dogmática nacional) com a jurisprudência da CorteIDH sobre o 
conteúdo e o alcance destes dispositivos e sobre as obrigações que a norma convencional impõe aos Estados signatários. Isso é assim porque o marco normativo supranacional não se restringe à literalidade da norma convencional, mas deve ser analisado à luz de seu contexto normativo de significação, em outras palavras, em conjunto com o acervo jurisprudencial emanado da corte responsável pela sua adjudicação (como intérprete qualificado de seus dispositivos) e pela interpretação dada pelos órgãos judiciais dos diferentes países igualmente signatários desse mesmo diploma internacional. Afinal de contas, a norma internacional deve ser interpretada de acordo com seu contexto.

Especificamente em relação à regra em comento, existem dezessete ${ }^{1}$ importantes precedentes da CorteIDH que enfrentaram especificamente esta questão ao tratar da análise da compatibilidade da ordem jurídica interna dos países com os ditames da Convenção.

Essas decisões exigem que se desencadeie uma profunda revisão da compreensão nacional sobre o alcance da garantia da imparcialidade do juízo. E isso porque, nos precedentes citados, a CorteIDH entendeu que a específica composição dos juízos militares (que em regra, como ocorre no Brasil, têm em seus colegiados membros das forças armadas), apresenta-se incompatível com a garantia de um juiz natural imparcial, especialmente por que a Corte considera que a justiça militar apenas e tão-somente se justifica à medida que julga militares por crimes estritamente militares.

Para subsidiar toda a abordagem a ser feita com vistas a atingir os fins da pesquisa, os referenciais teóricos adequar-se-ão a três grupos distintos. Primeiramente, a partir das obras de processualistas brasileiros, buscar-se-á configurar os limites de competência da justiça militar da União. Em um segundo momento, os referenciais restringir-se-ão às decisões da CorteIDH acerca do tema, em especial os cinco casos que para este artigo apresentam-se como mais importantes. Por fim, em um terceiro passo, entram em cena as obras de Ernesto Rey Cantor (2009) e Juan Carlos Hitters (2008), autores que exploram as dificuldades relacionadas à engenharia de articulação entre a ordem interna e internacional a ser desempenhado pelo juiz nacional, dentro do que se tem denominado controle de convencionalidade.

O artigo elenca como problema básico de pesquisa, portanto, a seguinte questão: “a configuração atual do ordenamento brasileiro que possibilita à justiça militar da União o julgamento de civis, compatibiliza-se com a jurisprudência da CorteIDH referente ao tema?"

\footnotetext{
${ }^{1}$ Os casos estão elencados na nota de rodapé número 5. Porém, como será esclarecido na sequência, somente 4 precedentes serão mais detidamente trabalhados, posto que são os únicos que versam exclusivamente sobre a impossibilidade do julgamento de civis pela justiça militar.
} 
Como objetivo geral, almeja-se verificar se (e em que medida) a possibilidade, ainda que restrita, de que a justiça militar da União julgue civis compatibiliza-se com a interpretação que a Corte Interamericana de Direitos Humanos confere ao disposto no art. 8, item 1, da Convenção.

No plano dos objetivos específicos, busca-se: apresentar, caracterizar e delimitar a competência da justiça militar da União; delimitar, a partir da jurisprudência da CorteIDH, o alcance e o sentido das garantias da imparcialidade e da independência, previstas no art. $8^{\circ}$, item 1, da Convenção; problematizar acerca dos mecanismos institucionais que se encontram à disposição do Brasil (no âmbito dos três poderes) para corrigir eventuais incompatibilidades entre a atual possibilidade de que a justiça militar da União julgue civis e o entendimento da CorteIDH acerca do tema. Cada um desses objetivos específicos serão enfrentados nas sessões desse trabalho.

Por fim, cabe ressaltar que a fim de cumprir os objetivos de pesquisa, será adotado o método indutivo tendo em vista que o sentido da imparcialidade e da independência na Convenção, bem como dos limites do foro militar, serão extraídos a partir de análises de decisões da CorteIDH.

\section{A JUSTIÇA MILITAR DA UNIÃO E SUA COMPETÊNCIA PARA JULGAR CIVIS}

No Brasil, dentre as "justiças" existentes, quatro possuem competência em matéria criminal, duas comuns (estadual e federal) e duas especiais (eleitoral e militar).

Dentre as especiais, adquire centralidade para este artigo a justiça militar, que no Brasil possui uma divisão bastante importante: justiça militar dos Estados e justiça militar da União, ambas, por certo, com matriz constitucional. ${ }^{2}$

A justiça militar dos Estados encontra-se disciplinada nos $\S \S 3^{\circ}$ a $5^{\circ}$ do art. 125 da $\mathrm{CF} / 88$ :

$\S 3^{\circ}$ A lei estadual poderá criar, mediante proposta do Tribunal de Justiça, a Justiça Militar estadual, constituída, em primeiro grau, pelos juízes de direito

\footnotetext{
${ }^{2}$ Cabe ressaltar que desde a Constituição de 1934 (art. 84: “Os militares e as pessoas que lhes são assemelhadas terão foro especial nos delitos militares. Este foro poderá ser estendido aos civis, nos casos expressos em lei, para a repressão de crimes contra a segurança externa do país, ou contra as instituições militares.") existe a previsão de que civis sejam julgados no foro militar. No período republicano, somente a Constituição de 1891 limitou o foro militar para o julgamento de militares (art. 77). As Constituições de 1937 (art. 111), 1946 (art. $108, \S 1^{\circ}$ ) e 1967 (art. $122, \S 1^{\circ}$, no texto original, e art. $129, \S 1^{\circ}$, no texto da EC $\mathrm{n}^{\circ} .1$ de 1969 ) sempre mantiveram a mesma redação apresentada no art. 84 da Constituição de 1934.
} 
e pelos Conselhos de Justiça e, em segundo grau, pelo próprio Tribunal de Justiça, ou por Tribunal de Justiça Militar nos Estados em que o efetivo militar seja superior a vinte mil integrantes. (Redação dada pela Emenda Constitucional $\mathrm{n}^{\circ} 45$, de 2004)

$\S 4^{\circ}$ Compete à Justiça Militar estadual processar e julgar os militares dos Estados, nos crimes militares definidos em lei e as ações judiciais contra atos disciplinares militares, ressalvada a competência do júri quando a vítima for civil, cabendo ao tribunal competente decidir sobre a perda do posto e da patente dos oficiais e da graduação das praças. (Redação dada pela Emenda Constitucional $\mathrm{n}^{\circ} 45$, de 2004)

$\S 5^{\circ}$ Compete aos juízes de direito do juízo militar processar e julgar, singularmente, os crimes militares cometidos contra civis e as ações judiciais contra atos disciplinares militares, cabendo ao Conselho de Justiça, sob a presidência de juiz de direito, processar e julgar os demais crimes militares. (Incluído pela Emenda Constitucional $n^{\circ} 45$, de 2004)

No que interessa ao presente artigo, vê-se da leitura dos dispositivos (especialmente do $\S 4^{\circ}$ ) que à justiça militar dos Estados compete somente o julgamento de militares acusados de crimes militares, ou seja, o critério é não apenas em razão da matéria (crimes militares), mas também em razão da pessoa (militares dos Estados).

Desse modo, ainda que existam - como será possível ver adiante - aspectos envolvendo a justiça militar dos Estados que poderiam ser questionados diante da jurisprudência da CorteIDH, este artigo não se preocupará com a justiça militar dos Estados.

Porém, situação diversa é a da justiça militar da União, estabelecida entre os artigos 122 e 124 da CF/88, que estabelecem a estrutura (art. $122^{3}$ ), a organização do Superior Tribunal Militar (art. $123^{4}$ ) e a competência da justiça militar da União, disciplinada no art. 124 da Constituição que, por sua centralidade para este artigo, é transcrito na sequência:

À Justiça Militar compete processar e julgar os crimes militares definidos em lei. Parágrafo único. A lei disporá sobre a organização, o funcionamento e a competência da Justiça Militar.

Percebe-se da leitura do dispositivo que ao contrário do que se passou com a justiça militar dos Estados, no que se refere à da União, a Constituição não especificou os critérios definidores da competência, deixando laconicamente à legislação infraconstitucional a definição "dos crimes militares".

\footnotetext{
${ }^{3}$ CF/88, Art. 122: "São órgãos da Justiça Militar: I - o Superior Tribunal Militar; II - os Tribunais e Juízes Militares instituídos por lei."

${ }^{4}$ CF/88, Art. 123: "O Superior Tribunal Militar compor-se-á de quinze Ministros vitalícios, nomeados pelo Presidente da República, depois de aprovada a indicação pelo Senado Federal, sendo três dentre oficiais-generais da Marinha, quatro dentre oficiais-generais do Exército, três dentre oficiais-generais da Aeronáutica, todos da ativa e do posto mais elevado da carreira, e cinco dentre civis. Parágrafo único. Os Ministros civis serão escolhidos pelo Presidente da República dentre brasileiros maiores de trinta e cinco anos, sendo: I - três dentre advogados de notório saber jurídico e conduta ilibada, com mais de dez anos de efetiva atividade profissional; II - dois, por escolha paritária, dentre juízes auditores e membros do Ministério Público da Justiça Militar.”
} 
Desse modo, considerando a recepção pela Constituição de boa parte do Decreto-lei n. 1.001/69, que instituíra o Código Penal Militar, faz-se necessário dele se socorrer para atingir o exato limite de competência da justiça militar da União. E segundo o art. $9^{\circ}$ do CPM:

Art. $9^{\circ}$ Consideram-se crimes militares, em tempo de paz:

I - os crimes de que trata este Código, quando definidos de modo diverso na lei penal comum, ou nela não previstos, qualquer que seja o agente, salvo disposição especial;

II - os crimes previstos neste Código, embora também o sejam com igual definição na lei penal comum, quando praticados:

a) por militar em situação de atividade ou assemelhado, contra militar na mesma situação ou assemelhado;

b) por militar em situação de atividade ou assemelhado, em lugar sujeito à administração militar, contra militar da reserva, ou reformado, ou assemelhado, ou civil;

c) por militar em serviço, em comissão de natureza militar, ou em formatura, ainda que fora do lugar sujeito a administração militar contra militar da reserva, ou reformado, ou assemelhado, ou civil;

c) por militar em serviço ou atuando em razão da função, em comissão de natureza militar, ou em formatura, ainda que fora do lugar sujeito à administração militar contra militar da reserva, ou reformado, ou civil;

d) por militar durante o período de manobras ou exercício, contra militar da reserva, ou reformado, ou assemelhado, ou civil;

e) por militar em situação de atividade, ou assemelhado, contra o patrimônio sob a administração militar, ou a ordem administrativa militar;

f) revogada. (revogada pela Lei $n^{\circ} 9.299$, de 8.8.1996)

III - os crimes praticados por militar da reserva, ou reformado, ou por civil, contra as instituições militares, considerando-se como tais não só os compreendidos no inciso I, como os do inciso II, nos seguintes casos:

a) contra o patrimônio sob a administração militar, ou contra a ordem administrativa militar;

b) em lugar sujeito à administração militar contra militar em situação de atividade ou assemelhado, ou contra funcionário de Ministério militar ou da Justiça Militar, no exercício de função inerente ao seu cargo;

c) contra militar em formatura, ou durante o período de prontidão, vigilância, observação, exploração, exercício, acampamento, acantonamento ou manobras;

d) ainda que fora do lugar sujeito à administração militar, contra militar em função de natureza militar, ou no desempenho de serviço de vigilância, garantia e preservação da ordem pública, administrativa ou judiciária, quando legalmente requisitado para aquele fim, ou em obediência a determinação legal superior.

Parágrafo único. Os crimes de que trata este artigo quando dolosos contra a vida e cometidos contra civil serão da competência da justiça comum, salvo quando praticados no contexto de ação militar realizada na forma do art. 303 
da Lei $\mathrm{n}^{\circ}$ 7.565, de 19 de dezembro de 1986 - Código Brasileiro de Aeronáutica. (Redação dada pela Lei $n^{\circ} 12.432$, de 2011)

Percebe-se da leitura do dispositivo que são várias as hipóteses em que se menciona, na definição de crime militar, a possibilidade de que sua prática se dê - e por consequência o julgamento ocorra na justiça militar da União - por civis. E como visto acima, a doutrina processual penal não tece maiores críticas a tal possiblidade, ao passo que como será visto ao final, o Supremo Tribunal Federal chancela a possibilidade de que a justiça militar da União julgue civis.

Contudo, como será visto no item seguinte, este não é o entendimento da Corte Interamericana de Direitos Humanos.

\section{A COMPETÊNCIA DAS JUSTIÇAS MILITARES E A GARANTIA CONVENCIONAL DO JULGAMENTO POR AUTORIDADE IMPARCIAL NA JURISPRUDÊNCIA DA CORTE INTERAMERICANA DE DIREITOS HUMANOS}

Em que pese todo o quadro acima exposto e que reflete uma concepção, até o momento quase unânime, de que, se a lei assim disser, pode a justiça militar da União julgar civis, opinião bastante distinta é a emanada da jurisprudência da CorteIDH.

No âmbito do Sistema Interamericano de Direitos Humanos, tem-se que a Convenção Americana, em seu art. $8^{\circ}$, item 1, fixa textualmente a garantia de ser julgador por um juiz imparcial e independente:

$8^{\circ}$ Garantias judiciais

1. Toda pessoa tem direito a ser ouvida, com as devidas garantias e dentro de um prazo razoável, por um juiz ou tribunal competente, independente e imparcial, estabelecido anteriormente por lei, na apuração de qualquer acusação penal formulada contra ela, ou para que se determinem seus direitos ou obrigações de natureza civil, trabalhista, fiscal ou de qualquer outra natureza.

A Convenção não avança na definição do que venha a ser exatamente o princípio da imparcialidade, tarefa que acabou ficando a cargo da CorteIDH, que em diversos precedentes, desde 1999 com o caso inicial Castillo Petruzzi vs. Peru, até 2015 com o Caso Cruz Sánchez e outros vs. Peru, veio densificando o exato significado das garantias convencionais no que se 
refere ao tema objeto deste trabalho. São pelo menos $17^{5}$ os precedentes em que a Corte enfrentou o tema.

Inclusive, na mais recente decisão publicada pelo CorteIDH (Caso Cruz Sánchez e Outros vs. Peru), o Tribunal sintetizou sua jurisprudência sobre o tema:

A Corte recorda que sua jurisprudência relativa aos limites da competência da jurisdição militar para conhecer fatos que constituem violações de direitos humanos tem sido constante no sentido de afirmar que em um Estado democrático de direito, a jurisdição penal militar há de ter um alcance restritivo e excepcional, e estar direcionada à proteção de interesses jurídicos especiais, vinculados às funções próprias das forças militares. Por isso, a Corte tem assinalado que no foro militar somente se deve julgar militares ativos pelo cometimento de delitos ou faltas que por sua própria natureza atentem contra bem jurídicos próprios da ordem. (OEA. Caso Cruz Sánchez e otros vs. Peru, parágrafo 397). ${ }^{6}$

Essa, pois, a posição da CorteIDH que se consolidou ao longo de 17 precedentes (indicados na nota de rodapé n. 5), da qual se percebe nitidamente a impossibilidade de que a justiça militar venha a julgar civis.

Dentre os vários casos analisados, cumpre destacar que 13 (treze) deles não abordam especificamente o julgamento de civis pela justiça militar, mas sim casos - não raros na América Latina - em que militares, extrapolando com dolo suas funções, praticaram crimes contra civis. Daí a afirmação segundo a qual "[...] a Corte tem assinalado de maneira reiterada que a jurisdição militar não é o foro competente para investigar e, se for o caso, julgar e condenar os autores de violações de direito humanos, senão que o processo dos responsáveis é sempre competência da justiça ordinária” (OEA. Caso Arguelles e outros vs. Argentina, parágrafo 148). ${ }^{7}$ A CorteIDH entende que, mesmo nestes casos, haveria violação às garantias de um juiz natural, independente e imparcial.

\footnotetext{
${ }^{5}$ São os seguintes os precedentes da CorteIDH sobre a matéria: (1) Caso Castillo Petruzzi e outros vs. Peru (1999); (2) Caso Cesti Hurtado Vs. Peru (1999); (3) Caso Durand e Ugarte Vs. Peru (2000); (4) Caso Cantoral Benavides Vs. Peru (2000); (5) Caso Las Palmeras Vs. Colombia (2001); (6) Caso 19 Comerciantes Vs. Colômbia (2004); (7) Caso Lori Berenson Mejía Vs. Perú (2004); (8) Caso do Massacre de Mapiripán Vs. Colômbia (2005); (9) Caso Palamara Iribarne Vs. Chile (2005); (10) Caso do Massacre do Pueblo Bello Vs. Colômbia (2006); (11) Caso Almonacid Arellano e outros vs. Chile (2006); (12) Caso La Cantuta Vs. Peru (2006); (13) Caso do Massacre de "La Rochela" vs. Colômbia (2007); (14) Caso Escué Zapata vs. Colômbia (2007); (15) Caso Tiu Tojín Vs. Guatemala (2008); (16) Caso Argüelles e outros Vs. Argentina (2014); e (17) Caso Cruz Sánchez e outros vs. Peru (2015).

${ }^{6}$ É de amplo conhecimento de todos os que trabalham com a jurisprudência da Corte Interamericana de Direitos Humanos a forma que o Tribunal utiliza para desenvolver suas decisões por meio de parágrafos. Por isso, considerando a significativa aceitação que tal método possui no meio especializado, e para que se tenha uniformidade no método de citação, as decisões da CorteIDH na citação autor-data trarão a menção à OEA, o nome do caso e o parágrafo da citação.

${ }^{7}$ Cumpre destacar que desde 1994, com a Convenção Interamericana sobre Desaparecimento Forçado, esse tipo de restrição já se fazia notar. Tanto que o art. IX da referida Convenção expressamente consigna: “Os suspeitos dos atos constitutivos do delito do desaparecimento forçado de pessoas só poderão ser julgados pelas jurisdições de direito comum competentes, em cada Estado, com exclusão de qualquer outra jurisdição especial,
} 
Dessa forma, os seguintes casos, que ficam aqui mencionados, não serão analisados aqui, ainda que constituam, no conjunto, mais uma hipótese de restrição de competência do foro militar: (1) Caso Cesti Hurtado Vs. Peru (sentencia de 29 de setembro de 1999); (2) Caso Durand e Ugarte Vs. Peru (sentença de 16 de agosto de 2000); (3) Caso Las Palmeras Vs. Colômbia (sentença de 06 de dezembro de 2001); (4) Caso 19 Comerciantes Vs. Colômbia (sentença de 05 de julho de 2004); (5) Caso do "Massacre de Mapiripán" Vs. Colômbia (sentença de 15 de setembro de 2005); (6) Caso do Massacre de Pueblo Bello Vs. Colômbia (sentença de 31 de janeiro de 2006); (7) Caso Almonacid Arellano e outros vs. Chile (2006); (8) Caso La Cantuta Vs. Peru (sentença de 29 de novembro de 2006); (9) Caso do Massacre de "La Rochela" vs. Colômbia (sentença de 11 de maio de 2007); (10) Caso Escué Zapata vs. Colômbia (sentença de 4 de julho de 2007); (11) Caso Tiu Tojín vs. Guatemala (sentença de

26 de novembro de 2008); (12) Caso Arguelles e outros vs. Argentina (sentença de 20 de novembro de 2014); e (13) Caso Cruz Sánchez e outros vs. Peru (sentença de 17 de abril de 2015).

No entanto, mesmo com a categórica síntese feita no recentíssimo Caso Cruz Sánchez e Outros vs. Peru (sentença de 17 de abril de 2015), na sequência proceder-se-á a uma breve recapitulação dos principais casos em que a CorteIDH criou a jurisprudência, a partir das garantias da imparcialidade e da independência, de que a justiça militar não pode julgar civis. Iniciar-se-á tal análise pelo Caso Castillo Petruzzi e outros vs. Peru.

\subsection{Caso Castillo Petruzzi e outros vs. Peru (sentença de 30 de maio de 1999)}

A jurisprudência que exclui do foro militar a presença do civil começar a nascer com o Caso Castillo Petruzzi e outros vs. Peru (sentença de 30 de maio de 1999). ${ }^{8}$ Trata-se de demanda que chegou à CorteIDH referente ao julgamento de quatro cidadãos chilenos por um "tribunal sem rosto" pertencente à justiça militar peruana.

Segundo depreende-se da própria decisão da Corte, até 1992, a legislação peruana somente admitia que civis fossem julgados pela justiça militar em caso de traição à pátria no

particularmente a militar. Os atos constitutivos do desaparecimento forçado não poderão ser considerados como cometidos no exercício das funções militares. Não serão admitidos privilégios, imunidades nem dispensas especiais nesses processos, sem prejuízo das disposições que figuram na Convenção de Viena sobre Relações Diplomáticas."

8 Antes, porém, de referido caso, a CorteIDH já havia se deparado com casos sobre a competência da justiça militar (Caso Genie Lacayo vs. Nicarágua, e Caso Loaiza Tamayo vs. Peru, ambos de 1997). Entretanto, particularidades dos casos levaram à desnecessidade de manifestação sobre os limites jurisdicionais da justiça castrense. 
contexto de guerra externa. Porém, após referida data, um decreto-lei estendeu tal possibilidade para todo e qualquer caso de traição à pátria, independentemente do tempo do crime, o que permitiu o julgamento de cidadãos chilenos, presos em Lima (Peru) e acusados de praticar o referido delito, pela justiça militar peruana.

Em sua decisão, a Corte advertiu que:

[...] la jurisdicción militar ha sido establecida por diversas legislaciones con el fin de mantener el orden y la disciplina dentro de las fuerzas armadas. Inclusive, esta jurisdicción funcional reserva su aplicación a los militares que hayan incurrido en delito o falta dentro del ejercicio de sus funciones y bajo ciertas circunstancias. En este sentido se definía en la propia legislación peruana (artículo 282 de la Constitución Política de 1979). El traslado de competencias de la justicia común a la justicia militar y el consiguiente procesamiento de civiles por el delito de traición a la patria en este fuero, supone excluir al juez natural para el conocimiento de estas causas. En efecto, la jurisdicción militar no es la naturalmente aplicable a civiles que carecen de funciones militares y que por ello no pueden incurrir en conductas contrarias a deberes funcionales de este carácter. Cuando la justicia militar asume competencia sobre un asunto que debe conocer la justicia ordinaria, se ve afectado el derecho al juez natural y, a fortiori, el debido proceso, el cual, a su vez, encuéntrase íntimamente ligado al propio derecho de acceso a la justicia. (OEA. Caso Castillo Petruzzi e outros vs. Peru, parágrafo 128)

Neste caso específico, parece ter pesado na decisão da CorteIDH o que dispunha o art. 282 da Constituição peruana, segundo o qual "Los miembros de las Fuerzas Armadas y Fuerzas Policiales en los casos de delitos de función están sometidos al Fuero respectivo y al Código de Justicia Militar, cuyas disposiciones no son aplicables a los civiles, salvo lo dispuesto en el Artículo 235. Quienes infringen el Servicio Militar Obligatorio están sometidos al Código de Justicia Militar." O mencionado artigo 235, por sua vez, estabelecia que "No hay pena de muerte, sino por traición a la Patria en caso de guerra exterior."

Já a atual Constituição do Perú, de 1993, estabelece em seu artigo 173, que versa sobre a competência do "foro privativo militar" que:

En caso de delito de función, los miembros de las Fuerzas Armadas y de la Policía Nacional están sometidos al fuero respectivo y al Código de Justicia Militar. Las disposiciones de éste no son aplicables a los civiles, salvo en el caso de los delitos de traición a la patria y de terrorismo que la ley determina. La casación a que se refiere el artículo 141 sólo es aplicable cuando se imponga la pena de muerte. Quienes infringen las normas del Servicio Militar Obligatorio están asimismo sometidos al Código de Justicia Militar.

Vale dizer, em sua interpretação do caso peruano, a CorteIDH identifica um retrocesso, na Constituição vigente, se considerado que a anterior era mais restritiva em matéria de competência da justiça militar. 
Ainda neste precedente, a Corte afirma que a ideia de independência do órgão judicial, insculpida no art. 8.1 da Convenção, em uma primeira leitura relaciona-se à justiça ordinária. Na concepção da Corte, a criação de uma justiça especial precisa de uma forte justificativa, o que não se faria presente no caso de a justiça militar julgar civis ou crimes não estritamente militares:

Constituye un principio básico relativo a la independencia de la judicatura que toda persona tiene derecho a ser juzgada por tribunales de justicia ordinarios con arreglo a procedimientos legalmente establecidos. El Estado no debe crear "tribunales que no apliquen normas procesales debidamente establecidas para sustituir la jurisdicción que corresponda normalmente a los tribunales ordinarios". (OEA. Caso Castillo Petruzzi e outros vs. Peru, parágrafo 129)

É certo que parece pesar na concepção da Corte os problemas de procedimento que se identificaram no caso Petruzzi e outros, mas de todo modo é nítida a afirmação - em que pese faltar um maior desenvolvimento - de que a independência repousa, inicialmente, na jurisdição ordinária.

Dois outros fatores que podemos denominar "peruanos" (porque específicos do caso em análise) pesaram na conclusão da Corte: (a) o fato de que ao mesmo tempo que às forças militares cabia combater o terrorismo, também lhe cabia julgar os terroristas; e (b) o fato de que os membros do Conselho de Justiça Militar eram indicados pelo Ministro de Estado que igualmente tinha como função o combate ao terrorismo. Para a Corte, tais fatos eram suficientes para que a independência (e também imparcialidade) dos juízes militares fossem postas em dúvida:

El juez encargado del conocimiento de una causa debe ser competente, independiente e imparcial de acuerdo con el artículo 8.1 de la Convención Americana. En el caso en estudio, las propias fuerzas armadas inmersas en el combate contra los grupos insurgentes, son las encargadas del juzgamiento de las personas vinculadas a dichos grupos. Este extremo mina considerablemente la imparcialidad que debe tener el juzgador. Por otra parte, de conformidad con la Ley Orgánica de la Justicia Militar, el nombramiento de los miembros del Consejo Supremo de Justicia Militar, máximo órgano dentro de la justicia castrense, es realizado por el Ministro del sector pertinente. Los miembros del Consejo Supremo Militar son quienes, a su vez, determinan los futuros ascensos, incentivos profesionales y asignación de funciones de sus inferiores. Esta constatación pone en duda la independencia de los jueces militares. (OEA. Caso Castillo Petruzzi e outros vs. Peru, parágrafo 130)

Em sua decisão, inclusive, a Corte invoca os "Princípios Básicos Relativos à Independência da Magistratura", adotados pelo Sétimo Congresso das Nações Unidas sobre Prevenção do Delito e Tratamento do Delinquente, celebrados em Milão e confirmados pela 
Assembleia Geral em suas resoluções 40/32 de 29 de novembro de 1985 e 40/146 de 13 de dezembro de 1985.

Cabe ressaltar, porém, como já mencionado, que parece ter pesado na decisão da Corte o fato de que os processos que tramitaram à época pela justiça militar peruana foram repletos de impropriedades e violações de garantias processuais (inclusive com “juízes sem rosto”). Tal impressão é reforçada pela ausência de uma maior digressão por parte da Corte sobre a exata relação entre justiça militar e imparcialidade. A Corte afirma em várias passagens o direito que possuem as pessoas de serem julgadas por tribunais ordinários, o que em parte leva a compreender os tribunais militares quase como tribunais de exceção, o que não exatamente ocorre quando tais órgãos judiciais são estabelecidos e mantidos a todo tempo e com procedimentos previamente estabelecidos em lei.

Nos julgamentos seguintes, porém, a ideia de que não cabe à justiça militar julgar civis parece que se desenvolve à revelia de maiores impropriedades na composição dos tribunais ou mesmo de violações de procedimentos.

\subsection{Caso Cantoral Benavides Vs. Peru (sentença de 18 de agosto de 2000)}

O segundo precedente, novamente refere-se ao Peru e diz respeito à atuação da DINCOTE, braço da polícia nacional peruana especializado em combate ao terrorismo, que no dia 06 de fevereiro de 1993, prendeu ilegalmente o senhor Luis Alberto Cantoral Benavides. Levado a julgamento por um foro militar sem rosto, o senhor Cantoral Benavides restou absolvido.

Após apresentar os argumentos da ComissãoIDH e do Estado peruano, a Corte, transcrevendo o art. 8.1 da Convenção e narrando o quadro de competência da justiça militar peruana (que permitia o julgamento de civis), estabeleceu:

Es necesario señalar que la jurisdicción militar se establece en diversas legislaciones para mantener el orden y la disciplina dentro de las fuerzas armadas. Por ello, su aplicación se reserva a los militares que hayan incurrido en delitos o faltas en el ejercicio de sus funciones y bajo ciertas circunstancias. En ese sentido se regulaba la jurisdicción militar en la legislación peruana (artículo 282 de la Constitución de 1979). El traslado de competencias de la justicia común a la justicia militar y el consiguiente procesamiento de civiles por el delito de traición a la patria en este fuero, como sucede en el caso, supone excluir al juez natural para el conocimiento de estas causas. Al respecto, la Corte ha dicho que "[c]uando la justicia militar asume competencia sobre un asunto que debe conocer la justicia ordinaria, se ve afectado el derecho al juez natural y, a fortiori, el debido proceso, el cual, a su vez, encuéntrase íntimamente ligado al propio derecho 
de acceso a la justicia" [citação do Caso Castillo Petruzzi]. (OEA. Caso

Cantoral Benavides vs. Peru, parágrafo 112)

Na sequência, a Corte transcreve citação feita no Caso Durand e Ugarte e que carteriza o standard interpretativo sobre a matéria:

[e]n un Estado democrático de Derecho la jurisdicción penal militar ha de tener un alcance restrictivo y excepcional y estar encaminada a la protección de intereses jurídicos especiales, vinculados con las funciones que la ley asigna a las fuerzas militares. Así, debe estar excluido del ámbito de la jurisdicción militar el juzgamiento de civiles y sólo debe juzgar a militares por la comisión de delitos o faltas que por su propia naturaleza atenten contra bienes jurídicos propios del orden militar. [Caso Durand y Ugart, párr. 117] (OEA. Caso Cantoral Benevides vs. Peru, parágrafo 113)

No caso em análise, o problema do envolvimento de militares no combate ao terrorismo e no julgamento de acusados de terrorismo, volta à tona:

Estima la Corte que los tribunales militares del Estado que han juzgado a la presunta víctima por el delito de traición a la patria no satisfacen los requerimientos de independencia e imparcialidad establecidos en el artículo 8.1 de la Convención. La Corte considera que en un caso como el presente, la imparcialidad del juzgador resulta afectada por el hecho de que las fuerzas armadas tengan la doble función de combatir militarmente a los grupos insurgentes y de juzgar e imponer penas a los miembros de dichos grupos. [...] (OEA. Caso Cantoral Benevides vs. Peru, parágrafo 114)

Ainda bastante preso ao quadro peruano da época, o segundo precedente avança pouco no esclarecimento sobre as razões que impediriam a justiça militar de julgar civis, ainda que seja uma decisão importante ao reafirmar concepções anteriormente apresentadas no caso Petruzzi.

\subsection{Caso Lori Berenson Mejía Vs. Peru (sentença de 25 de novembro de 2004)}

O terceiro precedente de interesse mais direito ao presente artigo é o caso da Sra. Lori Berenson Mejía contra o Peru, caso que se desenvolveu em situação semelhante ao exposto no item anterior.

Segundo consta da própria decisão da Corte, a Sra. Lori Berenson Mejía foi presa em 30 de novembro de 1995, para ser julgada conforme o Decreto Lei $\mathrm{N}^{\circ} 25.659$, por um tribunal militar "sem rosto", que em 12 de março de 1996 a condenou à prisão perpétua pelo delito de traição à pátria. Em 18 de agosto de 2000, em sede de recurso oposto pela defesa, o Conselho Supremo de Justiça Militar do Peru anulou a sentença, remetendo o caso à justiça ordinária. (OEA. Caso Lori Berenson Mejía vs. Peru, parágrafo 3) 
Ao analisar o fato de a Sra. Lori ter sido submetida inicialmente a julgamento pelo foro militar, a Corte, analisando o caso sob a ótica de um "juiz competente, independente e imparcial”, invocou precedentes anteriores para reafirmar que “[...] a jurisdição militar se estabelece para manter a ordem e a disciplina nas forças armadas" (OEA. Caso Lori Berenson Mejía vs. Peru, parágrafo 141), razão pela qual sua “[...] aplicação reserva-se aos militares que hajam incorrido em delito ou falta no exercício de suas funções e sob certas circunstâncias" (OEA. Caso Lori Berenson Mejía vs. Peru, parágrafo 141), como ser o militar da ativa e não se tratar de delito caracterizador de violação de direitos humanos de civis.

Ainda invocando seus próprios precedentes, a Corte relembra que a compreensão que possui sobre a matéria:

[e]n un Estado democrático de Derecho la jurisdicción penal militar ha de tener un alcance restrictivo y excepcional y estar encaminada a la protección de intereses jurídicos especiales, vinculados con las funciones que la ley asigna a las fuerzas militares. Así, debe estar excluido del ámbito de la jurisdicción militar el juzgamiento de civiles y sólo debe juzgar a militares por la comisión de delitos o faltas que por su propia naturaleza atenten contra bienes jurídicos propios del orden militar. (OEA. Caso Lori Berenson Mejía vs. Peru, parágrafo 142)

Dos parágrafos 138 a 150 da decisão, a Corte reafirma a impossibilidade de que a justiça militar julgue civis, insistindo que o fato de que aqueles que integram as forças armadas que têm por missão reprimir certos delitos (caso peruano) igualmente compõem tribunais militares, afeta a garantia da independência e imparcialidade, que se espera do julgador e que baliza o devido processo legal.

Com o caso Lori Berenson Mejía encerra-se a sequência de "casos peruanos" sobre a impossibilidade de julgamento de civis pela justiça militar. Com o caso seguinte, Palamara Iribarne vs. Chile, a Corte tem a oportunidade de especificar alguns argumentos sobre a matéria.

\subsection{Caso Palamara Iribarne Vs. Chile (sentença de 22 de novembro de 2005)}

O quarto precedente diz respeito ao Estado chileno, e possui uma particularidade: a vítima, o senhor Humberto Antonio Palamara Iribarne, já havia sido militar, mas na data dos fatos e do processo (perante o foro militar) já se encontrava desligado da Marinha chilena, ostentando a qualidade de ex-militar que possuía uma empresa que prestava serviços (na qualidade, pois, de civil) para as Forças Armadas de seu país. 
Nesse julgamento, a CorteIDH avançando no que havia estabelecido sobre o tema até então, nos fornece vários requisitos que devem ser atendidos para que seja válido o julgamento perante o foro militar:

En este sentido, las normas penales militares deben establecer claramente y sin ambigüedad quiénes son militares, únicos sujetos activos de los delitos militares, cuáles son las conductas delictivas típicas en el especial ámbito militar, deben determinar la antijuridicidad de la conducta ilícita a través de la descripción de la lesión o puesta en peligro de bienes jurídicos militares gravemente atacados, que justifique el ejercicio del poder punitivo militar, y especificar la correspondiente sanción. (OEA. Caso Palamara Iribarne Vs. Chile, parágrafo 126)

Na sequência, a decisão reafirma a necessidade de observância do requisito subjetivo (qualidade de militar) para que seja considerado convencional um julgamento perante a justiça militar, reafirmando sem margem de manobra a vedação ao julgamento de civis:

El Tribunal ha señalado que la aplicación de la justicia militar debe estar estrictamente reservada a militares en servicio activo, al observar en un caso que "al tiempo en que se abrió y desarrolló [el] proceso [en su contra], [la víctima tenía] el carácter de militar en retiro, y por ello no podía ser juzgad[a] por los tribunales militares". Chile, como Estado democrático, debe respetar el alcance restrictivo y excepcional que tiene la jurisdicción militar y excluir del ámbito de dicha jurisdicción el juzgamiento de civiles. (OEA. Caso Palamara Iribarne Vs. Chile, parágrafo 139)

Mas um dos mais emblemáticos pontos do caso Palamara Iribarne, diz respeito às considerações que faz a Corte sobre a ideia - central nessa matéria - da imparcialidade do julgador. A Corte afirma na decisão que "[a] imparcialidade do tribunal exige que seus integrantes não tenham um interesse direto, uma posição tomada, uma preferencia por alguma das partes e que não se encontrem envolvidos na controvérsia." (OEA. Caso Palamara Iribarne Vs. Chile, parágrafo 146) Ou seja, são 4 (quatro) os componentes de isenção do julgador: (a) ausência de interesse direto na causa; (b) ausência de uma posição tomada sobre o objeto da demanda; (c) ausência de preferencia por alguma das partes; e (d) não- envolvimento do julgador com a controvérsia objeto da demanda.

Na continuação da argumentação sobre a justiça militar, a Corte opera um cotejo detalhado sobre o quadro de composição da justiça militar chilena, encontrando em tal estruturação, pontos que julga incompatíveis com um julgamento imparcial e independente. Para a CorteIDH:

[...] la estructura orgánica y composición de los tribunales militares descrita en los párrafos precedentes supone que, en general, sus integrantes sean militares en servicio activo, estén subordinados jerárquicamente a los superiores a través de la cadena de mando, su nombramiento no depende de su competencia profesional e idoneidad para ejercer las funciones judiciales, 
no cuenten con garantías suficientes de inamovilidad y no posean una formación jurídica exigible para desempeñar el cargo de juez o fiscales. Todo ello conlleva a que dichos tribunales carezcan de independencia e imparcialidad. (OEA. Caso Palamara Iribarne Vs. Chile, parágrafo 155)

Esses, pois, os principais precedentes advindos da Corte Interamericana de Direitos Humanos sobre os limites e restrições de atuação da justiça militar.

\subsection{A incompatibilidade entre o quadro brasileiro de definição de competência da justiça militar da União e a posição da CorteIDH: elementos para o controle de constitucionalidade}

Como bem identifica Pablo Contreras V. (2011, p. 214), os precedentes da CorteIDH apontam duas vias de restrição da competência da justiça militar: (a) uma de ordem objetiva e (b) outra de natureza subjetiva. Ou, nas palavras do autor "[...]a categoria de indivíduos que podem ser submetidos a processos perante tribunais militares e a natureza objetiva dos delitos suscetíveis de conhecimento pelos mesmos.” (p. 214)

Sintetizando a jurisprudência da Corte sobre o critério subjetivo de definição da competência da justiça militar, Pablo Contreras V. (2011, p. 225) assinala:

[...] la Corte IDH ha interpretado que los civiles no pueden ser juzgados ante tribunales militares, sin excepción alguna. El estándar de la Corte IDH no admite puntos intermedios. Para ello, requiere que la definición de los delitos militares consigne claramente la conducta y el sujeto activo de la acción u omisión. Asimismo, la Corte IDH define el concepto de "civil" en términos negativos: todo aquel que es personal militar en servicio activo. Esta definición excluye a ex uniformados y a empleados civiles.

Fica patente, pois, que existe uma divergência entre a possibilidade - deixada em aberto pela Constituição de 1988 e chancelada pelo Código Penal Militar - de julgamento de civis pela justiça militar em tempo de paz, bem como do julgamento de militares da União por crimes praticados contra civis, e a posição da CorteIDH e a interpretação por ela conferida ao disposto no art. $8^{\circ}$, item 1 , da Convenção.

O fato é que a CorteIDH considera as normas internas - atos administrativos, leis, constituição, decisões judiciais - como "meros fatos", expressões de vontade dos Estados e procede ao cotejo destes fatos com a Convenção (RAMOS, 2003), buscando proteger a eficácia do objeto e fim do instrumento internacional (LONDOÑO LÁZARO, 2010). Constatando a incompatibilidade, declara a responsabilidade internacional do Estado por descumprimento da Convenção e condena-o a adequar o ordenamento interno à Convenção 
(REY CANTOR, 2009). Trata-se, portanto, de um exame de adequação de uma conduta do Estado com uma prescrição internacional estabelecida (LONDOÑO LÁZARO, 2010).

E, nesse contexto, não é dado aos Estados a faculdade de cumprirem ou não as determinações da CorteIDH, sob pena de descaracterização do próprio Sistema Interamericano de Proteção dos Direitos Humanos. Desse modo, fica patente a discrepância entre o estabelecido na Constituição brasileira no que se refere à possibilidade de julgamento de civis pela justiça militar da União, e o que entende a CorteIDH sobre a imparcialidade insculpida como garantia no art. 8.1 da Convenção.

No precedentes anteriormente citados, a par do reconhecimento do direito à reparação econômica pelo dano experimentado pela vítima, a Corte determinou aos Estados que realizassem, em um prazo razoável, a adequação de seus ordenamentos jurídicos nacionais à obrigação convencional tida por violada. Desta forma, a Corte determinou que fossem removidos os óbices legislativos e/ou que fosse adequada a norma processual doméstica a fim de que as diretrizes fixadas fossem devidamente incorporadas à legislação nacional.

A primeira conclusão a que se pode chegar, portanto, é de que a legislação nacional deve ser alterada, de forma que a possibilidade de que a justiça militar da União julgue civis seja abolida. Tal harmonização poderia se dar tanto por emenda à Constituição quanto - pela via mais fácil - da alteração do Código Penal Militar.

No entanto, defende-se neste artigo que a compatibilização do ordenamento jurídico interno não depende, exclusivamente, do desencadeamento de alterações legislativas (Emenda Constitucional e alteração na legislação correlata); mas a implementação das garantias convencionais pode ser realizada diretamente pelo próprio Poder Judiciário, por intermédio do exercício do controle de convencionalidade, como se verá adiante.

\section{CONTROLE DE CONVENCIONALIDADE $\mathrm{E}$ AS POSSIBLIDADES DE ADEQUAÇÃO DO ORDENAMENTO PÁTRIO AOS TERMOS DA CONVENÇÃO}

\subsection{Controle de Convencionalidade: conceito, histórico, fundamentos e operacionalização}

O controle judicial de convencionalidade surge no âmbito do sistema regional de proteção de direitos humanos americano "como uma ferramenta sumamente eficaz para o 
respeito, a garantia e a efetivação dos direitos descritos no Pacto [de San José da Costa Rica]" (SAGÜES, 2010, p. 118), resultado da construção pretoriana da Corte Interamericana (REY CANTOR, 2009). Por este controle, "as normas locais passam a ter a compatibilidade aferida diante das normas internacionais" (RAMOS, 2003, p. 86).

À semelhança da contraparte nacional (o controle de constitucionalidade), o controle judicial de convencionalidade afirma-se discursivamente como meio de salvaguarda dos direitos humanos previstos em normas plasmadas em documentos internacionais. Ademais, o recurso a este mecanismo igualmente é justificado a partir do recurso aos postulados da integridade sistêmica (unidade, coerência e completude dos ordenamentos jurídicos), como se depreende da função de preservação da integridade da Convenção Americana, assinalada por Alberto Lucchetti (2008), ou a preocupação em salvaguarda de uma suposta "aplicação harmônica do direito vigente" genericamente preconizada por Susana Albanese (2008, p. 15).

A noção de confrontação e de compatibilidade vertical fica evidente na definição analítica de Rey Cantor (2009, p. 8-9), para quem:

[...] [t]rata-se de um exame de confrontação normativa (material) do direito interno com a norma internacional, sobre alguns fatos - ação ou omissão internacionalmente ilícitos. A confrontação é uma técnica jurídica que se denomina controle, e tem por objeto "assegurar e fazer efetiva a supremacia" da Convenção Americana.

O marco histórico de assentamento do controle judicial de convencionalidade, no contexto interamericano é a decisão da CorteIDH no caso "Almonacid Arellano y otros vs. Chile" (26.9.2006), em que, pela primeira vez, uma decisão fez expressa alusão à terminologia "controle de convencionalidade" (HITTERS, 2008). Neste episódio, assim se pronunciou a Corte:

123. La descrita obligación legislativa del artículo 2 de la Convención tiene también la finalidad de facilitar la función del Poder Judicial de tal forma que el aplicador de la ley tenga una opción clara de cómo resolver un caso particular. Sin embargo, cuando el Legislativo falla en su tarea de suprimir y/o no adoptar leyes contrarias a la Convención Americana, el Judicial permanece vinculado al deber de garantía establecido en el artículo 1.1 de la misma y, consecuentemente, debe abstenerse de aplicar cualquier normativa contraria a ella. El cumplimiento por parte de agentes o funcionarios del Estado de una ley violatoria de la Convención produce responsabilidad internacional del Estado, y es un principio básico del derecho de la responsabilidade internacional del Estado, recogido en el Derecho Internacional de los Derechos Humanos, en el sentido de que todo Estado es internacionalmente responsable por actos u omisiones de cualesquiera de sus poderes u órganos en violación de los derechos internacionalmente consagrados, según el artículo 1.1 de la Convención Americana.

124. La Corte es consciente que los jueces y tribunales internos están sujetos al imperio de la ley y, por ello, están obligados a aplicar las disposiciones 
vigentes en el ordenamiento jurídico. Pero cuando un Estado ha ratificado un tratado internacional como la Convención Americana, sus jueces, como parte del aparato del Estado, también están sometidos a ella, lo que les obliga a velar porque los efectos de las disposiciones de la Convención no se vean mermadas por la aplicación de leyes contrarias a su objeto y fin, y que desde un inicio carecen de efectos jurídicos. En otras palabras, el Poder Judicial debe ejercer una especie de "control de convencionalidad" entre las normas jurídicas internas que aplican en los casos concretos y la Convención Americana sobre Derechos Humanos. En esta tarea, el Poder Judicial debe tener en cuenta no solamente el tratado, sino también la interpretación que del mismo ha hecho la Corte Interamericana, intérprete última de la Convención Americana. (sem grifos no texto original).

Posteriormente, no mesmo ano, no caso "Trabajadores Cesados del Congreso (Aguado Alfaro y otros) vs. Peru” (24.11.2006), a Corte ratificou a obrigatoriedade do controle judicial de convencionalidade, introduzindo elementos adicionais e tratando do tema de forma mais específica. Na ocasião, argumentou, no parágrafo 128 da decisão:

128. Cuando un Estado ha ratificado un tratado internacional como la Convención Americana, sus jueces también están sometidos a ella, lo que les obliga a velar porque el efecto útil de la Convención no se vea mermado o anulado por la aplicación de leyes contrarias a sus disposiciones, objeto y fin. En otras palabras, los órganos del Poder Judicial deben ejercer no sólo un control de constitucionalidad, sino también "de convencionalidad" ex officio entre las normas internas y la Convención Americana, evidentemente en el marco de sus respectivas competencias y de las regulaciones procesales correspondientes. Esta función no debe quedar limitada exclusivamente por las manifestaciones o actos de los accionantes en cada caso concreto, aunque tampoco implica que ese control deba ejercerse siempre, sin considerar otros presupuestos formales y materiales de admisibilidad y procedencia de ese tipo de acciones. (sem grifos no texto original).

Estes foram os dois principais pronunciamentos da Corte Interamericana sobre a temática (VILLANOVA, 2010), de cujas análises é possível perceber uma sensível evolução: na primeira decisão (caso “Almonacid Arellano”), a Corte faz menção ao dever do Poder Judiciário de realizar uma espécie de controle de convencionalidade, ao passo que no decisum ulterior (Caso Trabajadores cesados del Congreso) alude direta e categoricamente ao dever de exercer o controle de convencionalidade, consolidando a terminologia a partir de então (HITTERS, 2008). Conforme destaca Sagües (2010, p. 120), “[n]a última sentença, em síntese, o instituto de referência é apresentado, sem mais, como um ato de revisão ou fiscalização da submissão das normas nacionais à Convenção [...] e à exegese que a este instrumento dá a Corte Interamericana”.

Apesar de a Corte ter cunhado a expressão "controle de convencionalidade", trata-se, de fato, de um autêntico "controle judicial de convencionalidade", uma vez que o dever de exercê-lo é endereçado aos juízes - ao Poder Judiciário -, que devem realizá-lo quando o legislador esquivar-se de sua tarefa de suprimir ou de não editar normas contrárias à 
Convenção (GALVIS; SALAZAR, 2007; LUCCHETTI, 2008). Enfim, sinteticamente, o controle judicial de convencionalidade preconizado pela Corte Interamericana afigura-se como "um mecanismo jurídico pelo qual os juízes invalidam normas de hierarquia inferior à convenção, que não tenham sido ditadas de conformidade a ela, tendo em conta não somente a Convenção mesma, mas igualmente a interpretação que a ele efetua a Corte Interamericana" (SCHEPIS, 2009, p. 7).

Operam no controle judicial de convencionalidade tanto os juízes nacionais quanto a Corte Interamericana de Direitos Humanos. Em razão disto, a doutrina distingue duas classes do controle de convencionalidade, a saber: (a) controle de convencionalidade em sede interna; e, (b) controle de convencionalidade em sede internacional, respectivamente. (REY CANTOR, 2009; SAGÜES, 2010).

Em relação ao controle em sede interna, a Corte assinala que, previamente à realização da tarefa ordinariamente conhecida como subsunção - correlação do fato com a porção de direito aplicável -, o juiz nacional deve realizar o controle de convencionalidade entre a porção de direito doméstico aplicável e a norma convencional (VILLANOVA, 2010). Ainda de acordo com a preceito fixado pela CorteIDH, a prática de controle não se afigura como mera faculdade dos magistrados, mas consiste em um dever diretamente decorrente da obrigação convencional.

Portanto, os juízes nacionais encontram-se obrigados a rechaçar a norma interna “inconvencional" ex officio, independentemente de requerimento das partes (SAGÜES, 2010). Afirmar este dever de declaração ex officio, como assinala Hitters (2009), implica em conferir preponderância ao princípio do iura novit curia em detrimento do princípio da congruência (comum no direito processual interno de adstrição do magistrado às alegações das partes).

Havendo observância dos ditames convencionais e das pautas interpretativas fixadas pela Corte pelos juízes internos, não há necessidade de acudir ao sistema internacional (REY CANTOR, 2009). Em suma, o controle de convencionalidade é realizado previamente pela instância doméstica, donde a intervenção da Corte Interamericana só se realizará necessária em face da inoperância ou ineficácia dos órgãos nacionais. (HITTERS, 2008).

A título de conclusões parciais, pode-se perceber que, de acordo com a construção pretoriana da Corte Interamericana, o exercício do controle de convencionalidade incumbe primariamente aos próprios juízes nacionais e, de forma subsidiária, às instâncias de controle supranacional. Desta feita, o controle de convencionalidade a cargo da Corte Interamericana (controle de convencionalidade em sede internacional) constitui a atividade por excelência da 
Corte, sua razão de existir, que o realiza desde sua instituição, ao confrontar os fatos que traduzem a conduta dos Estados Partes com as normas convencionais. Não há novidade.

Por seu turno, o dever de controle de convencionalidade atribuído aos juízes nacionais (controle de convencionalidade em sede interna) é uma simples decorrência do dever geral de observar as obrigações internacionais assumidas pelo Estado - pacta sunt servanda. Sua deflagração está ligada diretamente ao reconhecimento de omissão ou inoperância das demais esferas de poder do Estado de adequar a ordem interna à Convenção e de respeitar as obrigações convencionais contraídas. Não há aqui, igualmente, grandes inovações teóricas.

Portanto, apresentada a incompatibilidade entre o texto da ConvençãoIDH e a intepretação que lhe confere a CorteIDH e a dinâmica recursal brasileira no âmbito do foro por prerrogativa de função, faz-se mister, no próximo item, apresentar e discutir alguns elementos de harmonização jurisprudencial com vistas a uma adequada efetivação do direito internacional dos direitos humanos.

\subsection{A competência da justiça militar da União em tempo de paz: elementos de compatibilização entre a Convenção e o quadro interno}

Como apontado ainda na introdução, a doutrina processual penal brasileira não enxerga maiores óbices no julgamento de civis pela justiça militar da União. Da mesma forma, o Supremo Tribunal Federal tem clara posição no sentido de tal possibilidade:

Ementa: Habeas Corpus originário. Competência da Justiça Militar da União. Interpretação restritiva. Civil acusado de Uso de Documento falso. Competência da Justiça Federal. Precedentes. 1. A jurisprudência do Supremo Tribunal Federal adota interpretação restritiva na definição da competência da Justiça Militar da União para o julgamento de civis em tempo de paz. 2. Compete à Justiça Federal processar e julgar civil acusado de uso de documento falso (art. 315 do CPM). 3. Ordem parcialmente concedida para declarar a insubsistência dos atos decisórios e determinar o encaminhamento dos autos à Justiça Federal. (BRASIL. Supremo Tribunal Federal. HC 121.189/PR)

No precedente, ainda que a ordem tenha sido concedida para remeter o processo à justiça federal, fica estampada a possibilidade de que a justiça militar da União julgue civis em tempo de paz.

Em outra decisão, agora com a ordem denegada, a posição fica mais clara:

Habeas corpus. 2. Crime de ingresso clandestino (art. 302 do CPM). Delito praticado por civis. 3. Competência para processo e julgamento. 4. A conduta de ingressar em território das Forças Armadas afronta diretamente a 
integridade e o funcionamento das instituições militares. Subsunção do comportamento dos agentes ao preceito primário incriminador consubstanciado no art. 9, inciso III, “a”, do CPM. Submissão à jurisdição especializada. 5. Reconhecida a competência da Justiça Militar da União para processar e julgar o crime de ingresso clandestino em quartel militar praticado por civis. Ordem denegada. (BRASIL. Supremo Tribunal Federal. HC 116.124/SP)

Um outro precedente chama ainda mais a atenção e demonstra a quase nenhuma afeição do Supremo Tribunal Federal pelo controle de convencionalidade. Trata-se de caso que, novamente em que pese a concessão da ordem para afastar a competência da justiça militar, inclusive com menção a ordenamentos estrangeiros e a precedente da CorteIDH, o Supremo Tribunal Federal inicia a ementa reafirmando a possibilidade, tendo em vista a abertura constitucional, de que a justiça militar da União julgue civis. Em que pese a extensão da ementa, sua transcrição faz-se imprescindível em razão da relevância para este artigo:

E M E N T A: [...] A competência penal da Justiça Militar da União não se limita, apenas, aos integrantes das Forças Armadas nem se define, por isso mesmo, "ratione personae". É aferível, objetivamente, a partir da subsunção do comportamento do agente - de qualquer agente, mesmo o civil, ainda que em tempo de paz - ao preceito primário incriminador consubstanciado nos tipos penais definidos em lei (o Código Penal Militar). - O foro especial da Justiça Militar da União não existe para os crimes dos militares, mas, sim, para os delitos militares, "tout court". E o crime militar, comissível por agente militar ou, até mesmo, por civil, só existe quando o autor procede e atua nas circunstâncias taxativamente referidas pelo art. $9^{\circ}$ do Código Penal Militar, que prevê a possibilidade jurídica de configuração de delito castrense eventualmente praticado por civil, mesmo em tempo de paz. - EXCLUSÃO, no caso, da competência penal da Justiça Militar da União quanto ao crime de roubo, por tratar-se de valores pertencentes a empresa privada, embora depositados em posto do Banco do Brasil em área sob a administração militar. Reconhecimento, no caso, da competência penal da Justiça comum estadual quanto ao suposto autor, que é civil. A REGULAÇÃO DO TEMA PERTINENTE À JUSTIÇA MILITAR NO PLANO DO DIREITO COMPARADO. - Tendência que se registra, modernamente, em sistemas normativos estrangeiros, no sentido da extinção (pura e simples) de tribunais militares em tempo de paz ou, então, da exclusão de civis da jurisdição penal militar: Portugal (Constituição de 1976, art. 213, Quarta Revisão Constitucional de 1997), Argentina (Ley Federal $n^{\circ}$

26.394/2008), Colômbia (Constituição de 1991, art. 213), Paraguai (Constituição de 1992, art. 174), México (Constituição de 1917, art. 13) e Uruguai (Constituição de 1967, art. 253, c/c Ley 18.650/2010, arts. 27 e 28), v.g.. - Uma relevante sentença da Corte Interamericana de Direitos Humanos ("Caso Palamara Iribarne vs. Chile", de 2005): determinação para que a República do Chile, adequando a sua legislação interna aos padrões internacionais sobre jurisdição penal militar, adote medidas com o objetivo de impedir, quaisquer que sejam as circunstâncias, que "um civil seja submetido à jurisdição dos tribunais penais militares (...)" (item no 269, n. 14, da parte dispositiva, "Puntos Resolutivos"). - O caso "Ex Parte Milligan" (1866): importante "landmark ruling" da Suprema Corte dos 
Estados Unidos da América. O POSTULADO DO JUIZ NATURAL REPRESENTA GARANTIA CONSTITUCIONAL INDISPONÍVEL, ASSEGURADA A QUALQUER RÉU, EM SEDE DE PERSECUÇÃO PENAL, MESMO QUANDO INSTAURADA PERANTE A JUSTIÇA MILITAR DA UNIÃO. - O princípio da naturalidade do juízo representa uma das mais importantes matrizes político-ideológicas que conformam a própria atividade legislativa do Estado e que condicionam o desempenho, por parte do Poder Público, das funções de caráter penal-persecutório, notadamente quando exercidas em sede judicial. O postulado do juiz natural reveste-se, em sua projeção político-jurídica, de dupla função instrumental, pois, enquanto garantia indisponível, tem por titular qualquer pessoa exposta, em juízo criminal, à ação persecutória do Estado e, enquanto limitação insuperável, incide sobre os órgãos do poder incumbidos de promover, judicialmente, a repressão criminal. - É irrecusável, em nosso sistema de direito constitucional positivo - considerado o princípio do juiz natural -, que ninguém poderá ser privado de sua liberdade senão mediante julgamento pela autoridade judiciária competente. Nenhuma pessoa, em consequência, poderá ser subtraída ao seu juiz natural. A nova Constituição do Brasil, ao proclamar as liberdades públicas - que representam limitações expressivas aos poderes do Estado -, consagrou, de modo explícito, o postulado fundamental do juiz natural. $\mathrm{O}$ art. $5^{\circ}$, LIII, da Carta Política prescreve que "ninguém será processado nem sentenciado senão pela autoridade competente". [...] (BRASIL. Supremo Tribunal Federal. HC

110.185/SP. Destacou-se)

Cabe destacar, ainda mais uma vez, a peculiaridade desse precedente do STF. Tratase de caso em que não seria difícil afastar a competência da justiça militar com a alegação de que sequer bens militares foram atingidos. Mas não. O voto do Ministro Celso de Mello, relator, adentra na discussão sobre o direito comparado e chega mesmo a citar a CorteIDH no Caso Palamara Iribarne vs. Chile, de 2005 - acima trabalhado - para, ao fim, a digressão ficar sem qualquer consequência prática. É emblemático que o Supremo Tribunal Federal, de quem se espera(ria) o controle de convencionalidade, frente aos compromissos internacionais assumidos pelo Brasil, demonstre conhecer a jurisprudência da CorteIDH para - na mesma ementa - negála.

Tentando fazer frente a esse quadro de paz interpretativa sobre a possibilidade de a justiça militar da União julgar civis que vigora no Brasil, o à época (2013) Procurador-Geral da República, Roberto Gurgel, ingressou com Arguiçao de Descumprimento de Preceito Fundamental (autuada com o número 289) perante o STF requerendo interpretação conforme à Constituição “ao art. 9 , I e III, do Decreto-lei n. 1.001, de 21 de outubro de 1969, com eficácia vinculante e efeito erga omnes, para que seja reconhecida a incompetência da justiça militar para julgar civis em tempo de paz e para que estes crimes sejam submetidos a julgamento pela justiça comum, federal ou estadual.” (Inicial da ADPF 289). 
Em que pese a relevância da ação (que já tramita no STF há 2 anos), cremos que para além de um controle de constitucionalidade com interpretação conforme, faz-se necessário um verdadeiro controle de convencionalidade à luz da jurisprudência da CorteIDH.

E isso por que, como visto, em decorrência da obrigação internacional de observância das regras pactuadas (pacta sunt servanda) e em atendimento à garantia constitucional de aplicabilidade direta e imediata dos direitos fundamentais (art. $5^{\circ}, \S 1^{\circ}$ da Constituição de 1988), os órgãos judiciais não podem se furtar do dever (constitucional e convencional) de conferirem plena eficácia às garantias jusfundamentais previstas em diplomas internacionais devidamente internacionalizados na ordem jurídica doméstica. Trata-se, pois, em última instância, de obrigação internacional reconhecida pela Corte Interamericana como controle de convencionalidade. Em outras palavras, do dever imposto aos juízes nacionais de remover os óbices legislativos (inclusive, decorrentes de omissão legislativa) que inviabilizam a plena eficácia das normas convencionais.

Nesse sentido, fica claro que são dois os caminhos para que o Brasil deixe o status de inconvencionalidade que permite que a justiça militar da União julgue civis e passe a um quadro de compatibilidade entre seu direito interno e o disposto na Convenção, seja em seu texto, seja na interpretação que lhe confere a CorteIDH.

O primeiro caminho seria uma alteração legislativa no Decreto-lei n. 1.001/69, mais especificamente no art. $9^{\circ}$, em todas as expressões que incluem o "civil" dentre os passíveis de prática de crime militar. Tal alteração, por óbvio, é de mais fácil consenso do que o caminho, igualmente eficaz, porém mais árduo de alterar o próprio texto constitucional, igualmente limitando a competência da justiça militar da União - como já feito com a justiça militar estadual - ao julgamento de civis.

Já o segundo caminho, aberto a todo e qualquer órgão do poder judiciário, mas especificamente aos juízes-auditores das auditorias militares, bem como aos do Superior Tribunal Militar e aos do Supremo Tribunal Federal, é o do controle de convencionalidade. Como visto, a partir de tal técnica, que na verdade não passa do cumprimento de um compromisso internacional assumido pelo Brasil, todo juiz, especificamente em ordenamentos como o nosso abertos ao controle difuso (incidental) de constitucionalidade, tem o dever de analisar a lei, não apenas pelo viés de sua compatibilidade com o texto constitucional, mas igualmente com o texto dos tratados e convenções sobre direitos humanos dos quais seu país seja signatário.

Nesse sentido, a todo juiz brasileiro incumbe o dever de não apenas controlar a constitucionalidade das leis e atos normativos que eventualmente tenha de aplicar, mas 
igualmente a convencionalidade de tais instrumentos, confrontando-os, não apenas com o texto de tratados e convenções sobre direitos humanos, mas igualmente com a interpretação que os intérpretes autorizados (Cortes, Comissões e Comitês) de tais documentos lhes dão.

E sendo assim, como visto acima, ao juiz brasileiro que se debruça sobre a questão da possibilidade do julgamento de civis pela justiça militar da União, não é dado escusar-se da interpretação (res interpretata) ${ }^{9}$ que a Corte IDH dá ao art. 8.1 da Convenção no sentido de que o julgamento de civis pela justiça militar, afronta as garantias de independência e imparcialidade estabelecidas no citado dispositivo.

\section{CONSIDERAÇÕES FINAIS}

Por mais que do ponto de vista da política legislativa e dos fins do Estado Democrático de Direito se possa estabelecer um debate sobre a pertinência da existência de uma justiça militar, ocorre que no âmbito do direito internacional dos direitos humanos não há problemas intrínsecos nessa opção tão adotada pelas atuais democracias constitucionais. Assim, o Brasil, valendo-se de sua soberania, pode decidir pela criação e atribuição de competências a uma especial justiça militar.

Contudo, ao mesmo tempo que tal opção abrange o âmbito soberano do País, e considerando a intrínseca relação entre questões processuais e um julgamento justo, à evidência, deve submeter-se aos direitos e garantias de cunho fundamental, sejam os previstos no texto constitucional, sejam aqueles decorrentes dos tratados e convenções dos quais o Brasil seja parte.

E quando tal harmonização não se mostrar presente, faz-se necessário recorrer aos canais de proteção dos direitos humanos para que o ruído seja silenciado. Nesse âmbito, o controle de convencionalidade adquire centralidade. Isso porque, como visto, a necessidade de realização do controle de convencionalidade, especialmente por parte do Poder Judiciário, decorre de obrigação internacional assumida pelo Brasil a partir do momento em que passa a integrar o Sistema Interamericano de Proteção dos Direitos Humanos.

Nesses termos, considerando que a Convenção Americana sobre Direito Humanos estabelece em seu art. $8^{\circ}$, item 1 , a garantia de um julgamento por um juiz natural, imparcial e independente, bem como que a jurisprudência da Corte IDH analisada nos precedentes

\footnotetext{
${ }^{9}$ Sobre a distinção entre res judicata e res interpretata no contexto da jurisprudência da Corte Interamericana de Direitos Humanos vide FERRER MAC-GREGOR, Eduardo, 2013.
} 
anteriormente trabalhados é firme no sentido de que a justiça militar não é apta a julgar civis, é mister que se trabalhe artifícios de compatibilização de nosso ordenamento com o disposto na Convenção.

Em vista de todo o exposto ao longo do presente artigo, é possível estabelecer duas cadeias de raciocínio: (1) se o Brasil assumiu um compromisso internacional de cumprir e fazer respeitar a Convenção Americana sobre Direitos Humanos; (2) que em seu artigo 8.1 estabelece as garantias de ser julgado por um juiz imparcial e independente; (3) o Brasil deve respeito a tal cláusula. Ocorre que: (1) no Brasil, a justiça militar da União tem, por abertura constitucional e opção legislativa, a competência para julgar civis; (2) ao passo que a Corte Interamericana de Direitos Humanos, intérprete autorizada da Convenção, em vários precedentes; (3) fixou o entendimento segundo o qual o julgamento de civis no foro militar frente as garantias insculpidas no art. 8.1 da imparcialidade e da independência.

Nesse contexto, faz-se imprescindível que o Brasil supere a violação convencional, seja pela alteração legislativa (reforma do art. $9^{\circ}$ do Código Penal Militar), seja pela atuação do Judiciário por meio de um controle de convencionalidade.

Por derradeiro, para que possa caminhar em direção a uma efetiva implementação da Convenção Americana sobre Direitos Humanos é imprescindível uma radical mudança de postura por parte dos órgãos judiciais brasileiros, notadamente da Corte Constitucional, para que passem a "levar a sério" o Sistema Interamericano de Proteção de Direitos Humanos, com especial atenção à jurisprudência da Corte Interamericana. $\mathrm{O}$ que não significa dizer que o judiciário doméstico deva recepcionar, irrestrita e irrefletidamente, a jurisprudência da Corte Interamericana como um autômato - fato este que não se compatibiliza com a noção de diálogo, senão de monólogo -, mas que confira a ela um valor argumentativo (vinculação argumentativa), abandonando definitivamente sua improfícua postura de recorrer a ela, somente quando conveniente, para corroborar seu discurso decisório (função retórica) por vezes sonegador de direitos humanos convencionais.

\section{REFERÊNCIAS}

ALBANESE, Susana [2008] (coord.). El control de convencionalidad. Buenos Aires: Ediar, 2008.

ALCALÁ, Humberto Nogueira. El debido proceso en la Constitución y el sistema interamericano: doctrina y jurisprudencia. 2. ed. Santiago: Librotecnia, 2012. 
BRASIL. Supremo Tribunal Federal. Primeira Turma. HC 121.189/PR. Relator Min. Rosa Weber. Relator p/ acórdão Min. Roberto Barroso. DJ-e 186 de 24.09.2014.

BRASIL. Supremo Tribunal Federal. Segunda Turma. HC 116.124/SP. Relator Min. Gilmar Mendes. DJ-e 171 de 30.08.2013.

BRASIL. Supremo Tribunal Federal. Segunda Turma. HC. 110.185. Relator Min. Celso de Mello. DJ-e 213 de 29.10.2014.

CONTRERAS V, Pablo. Independencia e Imparcialidad en Sistemas de Justicia Militar: Estándares Internacionales Comparados. Estudios constitucionales [online]. 2011, vol.9, n.2, pp. 191-248.

GALVIS, Maria Clara; SALAZAR, Katya [2007]. La jurisprudencia internacional y el procesamiento de violaciones de derechos humanos por tribunales nacionales.

Washington D.C., jan. 2007. Disponível em: 〈http://www.dplf.org/uploads/1191599742.pdf〉. Acesso em 25 set. 2010.

GOZAÍNI, Osvaldo Alfredo. El debido proceso. Santa Fe: Rubinzal-Culzoni Editores, 2004. FERRER MAC-GREGOR, Eduardo. Eficacia de la sentencia interamericana y la cosa juzgada internacional: vinculación directa hacia las partes (res judicata) e indirecta hacia los Estados Parte de la Convención Americana (res interpretata) (sobre el descumprimiento del Caso Gelman vs. Uruguay). Estudios Constitucionales, a. 11, n. 2, p. 641-694, 2013.

FLEMING, Abel; VINALS, Pablo López. Garantías del imputado. Santa Fe: RubinzalCulzoni Editores, 2007.

HITTERS, Juan Carlos. ¿Son vinculantes los pronunciamientos de la Comisión y de la Corte Interamericana de Derechos Humanos? (control de constitucionalidad y convencionalidad).

Revista Iberoamericana de Derecho Procesal Constitucional, n. 10, p. 131-156, jul./dez. 2008. Disponível em: 〈http://www.corteidh.or.cr/tablas/r25295.pdf >. Acesso em: 30 jul. 2015.

LONDOÑO LÁZARO, Maria Carmelina. El principio de legalidad y el control de convencionalidad de las leyes: confluencias y perspectivas en el pensamiento de la Corte Interamericana de Derechos Humanos. Boletín Mexicano de Derecho Comparado, ano LXIII, n. 128, p. 761-814, maio/ago. 2010. Disponível em:

<http://dialnet.unirioja.es/servlet/articulo?codigo=3212723>. Acesso em 20 mar. 2013.

LOPES JÚNIOR, Aury. Direito processual penal. 9. ed. São Paulo: Saraiva, 2012.

LUCCHETTI, Alberto J. [2008]. Los jueces y algunos caminos del control de convencionalidad. In: ALBANESE, Susana (org.). El control de convencionalidad. Buenos Aires: Ediar, 2008. p. 131-162.

MAZZUOLI, Valério de Oliveira [2009]. O controle jurisdicional da convencionalidade das leis. São Paulo: Revista dos Tribunais, 2009.

MENDES, Gilmar Ferreira; COELHO, Inocêncio Mártires; BRANCO, Paulo Gustavo Gonet. Curso de direito constitucional. 3. ed. São Paulo: Saraiva, 2008. 
OLIVEIRA, Eugênio Pacelli. Curso de processo penal. 16. ed. São Paulo: Atlas, 2012. ORGANIZAÇÃO DOS ESTADOS AMERICANOS. Corte Interamericana de Direitos Humanos. Caso Castillo Petruzzi e outros Vs. Peru. Fondo, Reparaciones y Costas. Sentencia de 30 de mayo de 1999. Serie C No. 52. Disponível em: http://www.corteidh.or.cr/ docs/casos/articulos/seriec_52_esp.pdf. Acesso em 15 jun. 2015.

Caso Cantoral Benavides Vs. Peru. Fondo. Sentencia de 18 de agosto de 2000. Serie C No. 69. Disponível em: http://www.corteidh.or.cr/docs/casos/articulos/seriec_69_esp.pdf. Acesso em 15 jun. 2015.

Caso Lori Berenson Mejía Vs. Peru. Fondo, Reparaciones y Costas. Sentencia de 25 de noviembre de 2004. Serie C No. 119 Disponível em: http://www.corteidh.or.cr/docs/casos/articulos/seriec_69_esp.pdf. Acesso em 15 jun. 2015.

Caso Palamara Iribarne Vs. Chile. Fondo, Reparaciones y Costas. Sentencia de 22 de noviembre de 2005. Serie C No. 135 Disponível em: http://www.corteidh.or.cr/docs/casos/articulos/seriec_69_esp.pdf. Acesso em 15 jun. 2015.

RAMOS, André de Carvalho. Tratados internacionais: novos espaços de atuação do Ministério Público. Boletim Científico da Escola Superior do Ministério Público da União, Brasília, ano 2, n. 7, p. 81-100, abr./jun. 2003.

REY CANTOR, Ernesto. Jurisdiccion constitucional y control de convencionalidad de las leyes. X Congreso Iberoamericano de Derecho Constitucional, Lima (Peru), 16-19 set. 2009. Disponível em: < http://congreso.pucp.edu.pe/derechoconstitucional2009/docs/pdf/PONENCIASMESAS/MESA\%201/REY\%20CANTOR,\%20Ernesto\%20_Colombia_\%20\%20Jurisdiccion....pdf >. Acesso em 12 mar. 2013.

SAGÜES, Nestor Pedro [2010]. Obligaciones internacionales y control de convencionalidad. Estudios Constitucionales, ano 8, n. 1, p. 117-136, 2010. Disponível em: <http://www.cecoch.cl/docs/pdf/revista_ano8_1_2010/articulo_4.pdf >. Acesso em: 20 set. 2010 .

SCHEPIS, Marcelo. La influencia de los tratados internacionales en el derecho interno. El control de convencionalidad. XXV Congreso Nacional de Derecho Procesal. Buenos Aires, 11-13 nov. 2009. Disponível em: <http://www.procesal2009bsas.com.ar/ponencias-constiproceso.html>. Acesso em 25 set. 2010.

VILLANOVA, Marcelo [2010]. Sobre el control de convencionalidad: a propósito de las implicancias del control en el sistema de garantías. Pensamiento Penal, 2010. Disponível em: <http://www.pensamienatopenal.com.ar/01072010/doctrina04.pdf>. Acesso em: 20 mar. 2013. 